\title{
Status of Industrialized Building System Manufacturing Plant in Malaysia
}

\author{
Mohamed Nor Azhari Azman, Mohd Sanusi S. Ahamad, Taksiah A.Majid, and Mohd Hanizun Hanafi
}

\begin{abstract}
The trend construction industry have move from project based to product based in term of long term investment. Industrialized building system (IBS) in Malaysia is defined as a construction system where components are manufactured at factories on or off site, transported and then assembled into a structure with minimum work. IBS also is known as off-site construction or prefabrication. Thus, IBS have the similarity drive and challenge with the United States (US), United Kingdom (UK) and Australia; and among the factors are skilled craft worker, fast track completion, cost and transportation. United States, United Kingdom and Australia have achieved modular building standard while Malaysia still in the hybridization stage. The Malaysian government and researcher have promoted the modern method construction industry to break the 'traditional technology'. Anecdotally, the total number of IBS manufacturing plant has increased from 21 in 2002 to 143 factories in 2010. From the evolution of the IBS manufacturing component, the most favorable system used in the IBS component is the precast concrete system and followed by the steel framing system.
\end{abstract}

Keywords: Reviews, Degree of Construction Industry, Appropriate Technology, Research Development and Management

\section{INTRODUCTION}

$\mathrm{T}_{\mathrm{i}}^{\mathrm{h}}$ he latest development in technology and global standardization has changed the past practice of the construction industry. This has affected land resources, social environment and local skills to cater the demand from the public and private sector. In the early stage of development of the construction industry, construction technology was imported from overseas in order to accelerate the pace of development and to ensure the increase in productivity of the construction sector. In order to fabricate mass production and high-quality products, factors such as the environment, level of workers skills, knowledge competence and resources need to be taken into account. It is vital to ensure that the technology can adapt to the local condition and the needs of the construction industry.

As reported Badir [1] the common use of the IBS components in Malaysia is for the frame system, panel system, box system, block system and the steel frame system but the percentages use of the IBS components is still low. Since the government has mandated that at least $70 \%$ of IBS components should be use in government project, there is a phenomenal change in the construction industry with the move towards the prefabrication stage. This has increased the number of IBS manufacturers in Malaysia and the Construction Industry Development Board (CIDB) as part of the government agency has played an important role to educate the industry.

The US and Japan have the biggest construction industry in the world and are well prepared with their global strategies [2]. The three factors that determine the ability of construction industries to enter the international market are technological advantages that are associated with possessing formidable construction technologies; sophisticated management systems for scheduling, material tracking, organized sub-contractors; and financing capability that enables a company to arrange for project financing schedules from international financiers. Technology is an important tool to push the construction industry to achieve the international level. This will help construction companies to achieve long-term profitability and acquire a balance growth in the future. The four countries involved in the studies are US, UK, Australia and Malaysia. The off-site manufacturing in the U.S. was started by Henry Ford [3]. It was a big evolution that became a phenomena and spread to the

Mohamed Nor Azhari Azman is a PhD candidate from the School of Civil Engineering, Universiti Sains Malaysia, 14300 Nibong Tebal, Penang, Malaysia . (phone: +604-5996277; fax: 5941009; e-mail: syurga7181@yahoo.com).

Assoc. Prof. Dr. Mohd Sanusi S.Ahamad is with the School of Civil Engineering, Universiti Sains Malaysia, 14300 Nibong Tebal, Penang, Malaysia (cesanusi@eng.usm.my)

Assoc. Prof Dr. Taksiah A. Majid is with the School of Civil Engineering, Universiti Sains Malaysia, 14300 Nibong Tebal, Penang, Malaysia (taksiah@eng.usm.my)

Dr Mohd Hanizun Hanafi is with the School of Housing Building and Planning, Universiti Sains Malaysia, 11800, Penang, Malaysia. (hanizun@gmail.com) 
rest of the world. UK and Australia have the similarity in terms of the approach towards research and categorization of offsite system. Malaysia adapted the advanced approach practiced by other countries.

In the US, off-site manufacturing in the construction industry is described as Off-site Construction Techniques (OSCT). However in the UK, the Modern Methods of Construction (MMC) is the term used by the government to describe a number of innovations in house building, most of which are off-site technologies. The term Offsite Manufacturing (OSM) is the term used both in Australia and the UK construction industry. The UK and Australia have shared the knowledge and the expertise of construction industry. Malaysia is well known by Industrialized Building System (IBS).

This paper is divided into two sections. The first section explained the pattern of performance in the manufacturing sector by illustrating the similarity of the construction industry in US, UK, Australia and Malaysia. The second section reviews the status of IBS manufacturers in Malaysia.

\section{SIMILARITY OF PREFABRICATION IN THE CONSTRUCTION INDUSTRY}

The building sector has yet to undergo a complete phase of industrialization. Yet, if a car was produced the way a building is delivered, very few people would be able to own one; if a computer was produced the way a building is delivered, it would cost a fortune [4]. This demand can be met by means of the advanced technology used in the Industrialized Building System (IBS) or prefabrication system. Malaysia possesses the "hardware elements" of the industrialized building systems technology with only a little concern on the structure, but still lacks the "software elements" regarding availability of data and information on the system, users, clients, manufacturers and assembly layout and process, as well as allocation or resources and material [1]. Most of the construction industries have the resources but still lack on the constructability concepts and the advanced technology that can enhance the speed of construction, improve the quality of the structure and be able to protect the environment. However, the concept of constructability started in the late 1960s to integrate the optimum use of construction knowledge and experience in the conceptual planning, detail engineering, procurement, and conduct field operations in phases to achieve the overall project objectives; and ease of construction [5]. The constructability concept has been extensively developed and applied in US, UK and Australia as well as in Malaysia where numerous studies have proved that constructability concept manage to save cost and time in the process of completion of the projects [6-8].

The evolution of car manufacturing started by Henry Ford with the standard production line had attracted the Toyota's President, Eji Toyoda, to spend three months at Ford's Rouge plant in the USA [3]. This has resulted in Toyota developing a new approach towards lean production, use of plant, management resources, quality control and relationship between producers and consumers [3, 9]. The great influence of the highly successful manufacturing system in Japan has resulted in researchers from US and UK coming to Japan to learn from the Japanese experience [3, 10, 11]. Unlike the other countries, majority of the Japanese construction research is conducted by private institutes; with the 'big-six' Japanese contractor; Kajima, Kumagai- Gumi, Obayashi, Taisei, Takanaka and Shimizu where the companies provide an annual contribution of $1 \%$ of their turnover to research and development [10]. The Japanese is more advanced in the field of technology of automation and robotics in the construction industry. This situation have motivated the others countries to move towards the advanced technology in order to gain competency in the industry. The phenomenal transition from conventional construction to prefabrication stage is not just occurred not only in the US and Japan but such similar prefabrication system ia also implemented in UK, Australia and Malaysia.

\section{THE GENERAL TERM OF METHOD OF CONSTRUCTION}

Prefabrication is a manufacturing process generally taking place at a specialize facility, in which various materials are joined to form a component part for final installation [12]. But on the other hand the prefabrication process could also run onsite (onsite fabrication). While off-site construction is a description of the spectrum or part which are manufactured or assembled remote from building site prior to installation in their final position [13]. Thus prefabrication is use by the term off-site construction as well as Off-Site Construction Techniques (OSCT); Modern Method of Construction (MMC); Off-Site Manufacturing (OSM) and Industrialized Building System (IBS).

$\mathrm{Lu}$ [14] reported that the OSCT study is limited and it would be beneficial to investigate the level of degree of these techniques in the US construction industry. MMC has been introduce by the UK Housing Corporation and the Office of the Deputy Prime Minister and is define as an efficient product management process such as pre-fabrication, off-site production and off-site manufacturing (OSM) to provide more products of better quality in less time as well as to improve the delivery of large-scale projects in terms of efficiency and cost [15]. In addition, MMC is as a tool to describe for the both off-site based construction techniques and innovative on-site technologies. As a result, policymakers have recognized that the use of modern methods of construction should be encouraged in order to both facilitate and stimulate house-building. 
In UK, Off-Site Manufacture (OSM) is just a part of the product management process but in Australia it is as a whole process and yet there is similarity on definitions and collaborate in networking research. The term OSM has been well known in Australia and internationally such as in UK, US and European countries. OSM is similar to the term used in Off-Site Fabrication (OSF), Off-Site Production (OSP), Off-Site Construction (OSC), pre-assembly and prefabrication [16, 17]. But for consistency in using the construction term in Australia, OSM was used as being stated in the Construction 2020 Report [18]. Off-Site Manufacture (OSM) is defined as the manufacturing and preassembly of components, elements or modules before installation into their final location [16]. The degree to which such preassembly takes place can however vary greatly, ranging from basic sub-assemblies, which are largely taken for granted, to entire modules.

According to Kamar [19] there are six main characteristics of existing IBS definition which are industrialized production, transportation \& assembly technique, onsite fabrication, mass production, structured planning and standardization and integration. The main function of the IBSs is to create synergy, by generating partners in the industry to assist in training, giving exposure on use of IBS techniques, encouraging the setting up of new IBS factories locally, updating on the latest technology, and enhancing current issues on IBS in the local state and international level [20].

The definitions for the term OSCT, MMC, OSM and IBS have the interrelated concept of prefabrication and onsite fabrication. Not all MMC is IBS, but all IBS is under MMC. The offsite and manufacturing technique is essential to IBS but onsite IBS method can be used in the form of in-situ pre-cast system. Thus, the paper concludes that all offsite is IBS, but not all IBS is offsite. Whereas all OSM and OSP may be regarded as failing within a generic MMC heading, not all MMC may be regarded as OSM and OSP. In this family, Prefabrication, Off-Site Construction Techniques (OSCT), Offsite Manufacturing (OSM) and Offsite Production (OSP) are largely interchangeable terms that refer to the part of construction process which is carried out away from the building site, such as in a factory or sometimes in specially created temporary production facilities close to the construction site (or field factories) [17]. The relationship of definitions for methods of construction is shown in figure 1 .

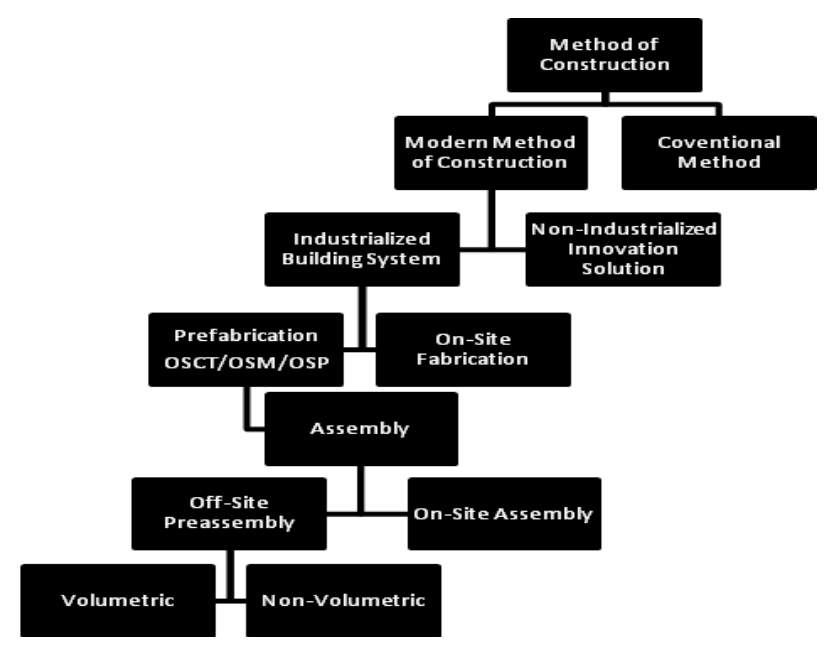

Figure 1. Terminology used in the Method of Construction Industry (Source: Modified from Kamar [19])

With regards to the development of technology for the off-site construction industry and the various of off-site construction industry system, the government and the researchers have come out with a guideline categorizing the off-site system as show in table 1. Table 1 also shows the pattern and the degree of technology changes. The US, UK and Australia have achieved the modular building standard but Malaysia is still in the initial stage to achieved it. In addition, the category of assembly method can be categorized as onsite and off-site. Preassembly which literally means to 'assemble before', constructed the manufacturing plant and assembly (usually off-site) of buildings or parts of buildings earlier than they would traditionally be constructed on-site [21]. Thus the off-site can be divided into preassembly and onsite assembly. The three countries have the similarity in off-site preassembly but UK and Australia have divided the off-site preassembly into non-volumetric and volumetric order. Thus, UK and Australia share the same similarity in the categorization of off-site system where most of the Australian researchers referred to UK. Malaysian researchers generally refer to the Australian and UK off-site system. Malaysia is still in the stage of hybridization system and the evolution pattern of the categorization of off-site system is shown in figure 2.

Table 1. Categorization of off-site system 
UNIMAS E-Journal of Civil Engineering, Vol. 2 (2) 2011

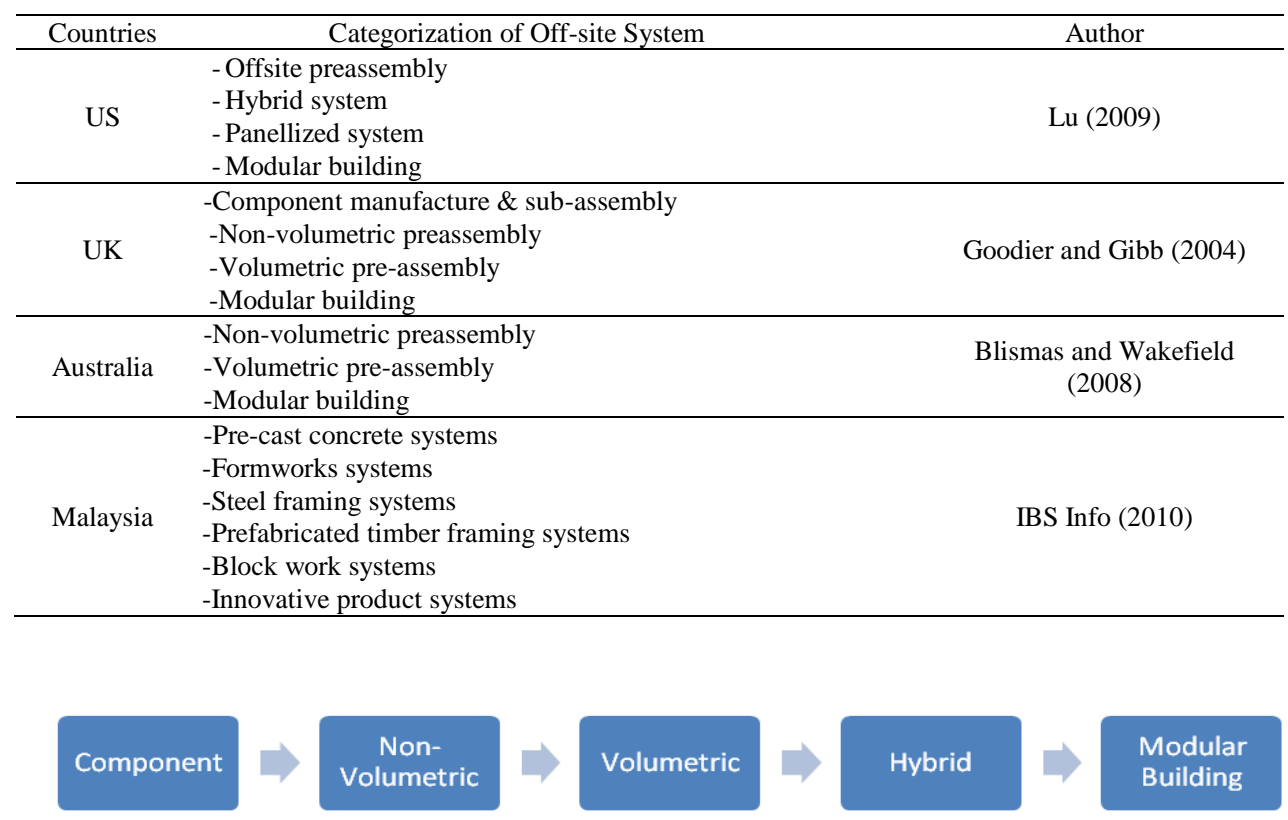

Figure 2. Evolution pattern of off-site construction industry

\section{The Similarity IN THE Drive AND Challenge to InTROdUCE THE MODERn Method OF CONSTRUCTION INDUSTRY}

\section{Skilled Craft Worker}

U.S. has the highest spending capital on construction with seventy-four percent of the total spent capital in world construction [22]. Yet, they still face problems at the off-site construction industry as reported in CMAA [23] where more than 40\% of the Construction Management Association of America experienced construction schedule overruns due to the shortage of skilled craft workers and resulted in escalation of project costs. Thus, this situation also occurred in UK and Australia as the main drive of the MMC and OSM industry. As reported by [24-26], the construction industry is having the most prominent shortage of skilled worker especially in the remote areas and high growth capital cities. Associated with the difficult situation the traditional tradesmen also find difficult to fulfill the requirement for higher onsite precision and to deal with the low tolerance of the tasks. The situation also happens in Malaysia, where the main objective of introducing IBS is to reduce the number of foreign workers. Although Malaysia can easily attract foreign workers to work here, but due to the huge number of foreign workers working in Malaysia, it has affected the employment opportunities for the locals. By using the IBS method, Malaysia is able to reduce the number of foreign workers in 2006 by $4 \%$ as shown in table 2. With the appropriate use of technology and systematic work in the industries, the use of IBS can gain the same productivity but with better outcome.

Table 2. Percentage of Foreign Workers to Total Construction Workforce

\begin{tabular}{lcccc}
\hline Items & 2003 & 2004 & 2005 & 2006 \\
\hline Local Workforce & 224,877 & 272,053 & 334,704 & 309,528 \\
Foreign Workers & 231,184 & 265,925 & 264,853 & 281,780 \\
Total & 456,061 & 537,978 & 599,557 & 591,308 \\
Percentage of Foreign Workers & $51 \%$ & $49 \%$ & $48 \%$ & $44 \%$ \\
\hline
\end{tabular}

Source: Department of Immigration Malaysia (MOF,2005) and Construction Industry Development Board (CIDB) Malaysia

\section{Fast Track Completion}

Generally, the use of OSCT, MMC, OSM and IBS is the main drive is reduced the construction time and project overall schedule as well as reduced site cost and generate early income for clients [14, 24, 26, 27]. Anecdotally, research by Kadir [28] in comparing the conventional building system and IBS in terms of labor productivity, crew size and cycle time proved that IBS manages to meet the target to reduce dependency on foreign labor, to improve construction productivity and quality, to achieve design standardization and to speed up construction time as mentioned in IBS [29]. In other words, the conventional building system was 70 per cent less productive than IBS in the completion of structural elements of one house unit. This result was in agreement with previous studies carried out by Trikha and Ali [30] which indicated that IBS saved about $75 \%$ time in the completion of projects under favorable circumstances. 
The main barrier in using modern method of construction industry is the high initial capital, higher design, crane and transport cost incurred which is agreed by [14, 24, 26, 27]. The high initial capital can be overcome by sufficient volume and ability to reduce mould cost with repetition use of the design. The higher repetition in use of the design may save the cost of mould and the ability produce design layout suit especially for high rise building and high repeatable of houses design. That is why high technology is required in order to have the ability to produce any types of building and to achieve the high end standard of modular building which is produced by manufacturing.

Malaysia is still in the process to achieve the modular building and is currently in the stage of hybridization system as well as open system. Most of the IBS system projects in Malaysia apply the "close system" where the components would only cater for a specific project and the factory would be closed after the project is completed. The government has taken action by introducing the "open system" by re-branding the concept of prefabrication "Industrialized Building Systems", creating a better response from the industry.

Based on the ManuBuild [31], open building manufacturing system is an integrated system that holistically incorporates building concepts, business processes, production technologies and ICT support as well as training. This enables future construction to act as a flexible, agile, value-driven, and knowledge based industry, and most of all to be highly customer centric, efficient and competitive.

\section{Transportation}

The transportation issue is the main drive and constraint faced by OSCT, MMC, OSM and IBS where it is an essential mechanism in order to carry heavy load and have the specific measurement of height and width to get through the federal road or highway as well as to pass through the low density of city or high development area. The contractors also need to decide appropriate weight crane to carry and erect the non-volumetric component and the volumetric structure. Thus, the safety and proper erection is important to ensure the component is not defect and require high precision during the installation process. Apart from the effective distance to transport the component to the site, it is also important to have the component in partial size where it can be 'plug and play' to become large scale structure. The main reason why the manufacturer chooses to produce partial size for components is to enhance the effectiveness of erection, easy transport to the site construction and save cost to hire the appropriate crane. Also, to save the transportation cost of size truck and the number of travelling require to have the appropriate size and weight of component; suitable weight carry and economic value crane to erect the component; high safety installation; proper in sequence order of component to avoid the component defect and hard to carry out due to improper arrangement of component at site construction.

\section{Barrier to Educate the Construction Industry}

The great challenge faced by the construction industry in UK is to integrate the 'traditional' technology with the appropriate off-site technology. In UK, the strong 'traditional' technology that comprises of brick/concrete block cavity wall methods, timber/precast floors and timber truss roofs [26]. Thus, the house buyers are strongly influenced by the negative perceptions of the MMC innovation in housing construction that it will spoil the authentic 'traditional' house image [32]. This has a effect the construction industry and the innovation building technologies where the industry players faces difficulty in implementing new concepts to the building system [26,33]. Notwithstanding, the MMC is also known as OSM [10]. UK and Australia have the similarity in applying the OSM in their countries. Goodier and Gibb [16] have difficulty in accessing the historic value of OSM in Australia. Thus a vague boundary exists between the traditional and OSM approaches, as well as data report on the performance of the construction and manufacturing industries.

As for Malaysia the contractors are comfortable with the conventional method that is cheaper than IBS system but the situation has changed with Malaysia facing the problem of shortage in houses. As a result, the Malaysian Ministry for Local Government and Housing reported that IBS have the speed of construction, quality product and economics value as well as the capability to produce bulk production and to overcome the shortage of houses [34]. Although, Malaysia has tried hard to introduce IBS since the 60's but received passive response from the construction industry and also to overcome the delay in construction projects as mentioned by $[35,36]$. The response from the construction industry changed when the government enforced the ruling in 2008 where the use of a minimum of $70 \%$ IBS method will receive the 50 percent levy from the government. The exemption of the levy (CIDB levy $-0.125 \%$ of total cost of the project according to Article 520) on contractors that implanted some kind of IBS in $70 \%$ of the building components was introduced effective from 31 October 2008. Act 520 in short, the act came into force on 24 July 1994 to establish CIDB as the governing body entrusted with the responsibility to provide effective leadership and coordination among Construction Industry players in Malaysia [37].

The IBS Survey 2008 also indicates that the awareness of construction industry in IBS knowledge and its application increased between 2003 and 2008 [27]. The scenario of construction industry in Malaysia has changed by the implementation of the IBS technology initiated by the Construction Industry Development Board (CIDB) Malaysia. The 50 percent of levy is used by the CIDB to educate the construction industry through by form of policies, financial incentive, strategy guidelines, workshops, seminars to increase the awareness among the end users and clients [38]. 
In order to educate the construction industry, the government of Australia and researchers have also played vital role to come out with a master planned of C2020 Vision for future construction industry of Australia [24]. The national research has established the Cooperative Research Centre (CRC) in 2001 to determine the 'state-of-the-art' OSM in Australia. They analyzed the problem encountered on OSM usage in the construction industry and recognized future investment and research to dissolve the setbacks [24]. While in US, Lu [14] suggested that the construction industry need to develop R\&D in the area of customized design and alternative materials; provide training; and increase the awareness among the manufacturers, general contractors and designers in the use of OSCT as well as to collaborate the vital players of construction industry to minimize the possibility of onsite changes.

\section{THE CURRENT IBS STATUS}

In an era of increasingly rapid technological changes, IBS is expected to play a greater role in ensuring improvement in construction activities and sustainable economic growth. The commitment of the government in encouraging the use of this approach can be seen with the development of the IBS Roadmap 2003-2010 [39]. The IBS Roadmap was approved by the Cabinet Ministers on October 2003 with the aims of providing guidelines towards the establishment of an industrialized construction sector as well as achieving an open construction system by the year 2010. The development of this roadmap was based on the 5M strategy (machinery, manpower, material, measurement, and method) and will be implemented gradually for government projects [20]. This IBS guideline targets as much as $70 \%$ of the government projects to be in the category of buildings using the IBS approach in Malaysia by 2008. The CIMP is also intended to ensure that the construction industry is well positioned to support the nation's overall economic growth and in meeting various challenges, such as the need to enhance productivity and quality along the entire construction industry value chain [39].

The shift in the trend of construction industry in Malaysia is shown in Table 3. This scenario has led to the encouragement of IBS adoption in construction activities in order to reduce dependency on foreign labors, to improve construction's productivity and quality, environmental friendly, to achieve design standardization and to speed up construction time. Anecdotally, based on the IBS Survey (2008), the ranking of IBS benefits listed from the most beneficial to the least beneficial are (1) minimal wastage; (2) cleaner environment; (3) less site materials; (4) reduction of site labor; (5) controlled quality; (6) faster project completion; (7) neater and safer construction sites; and (8) lower total construction costs. There is no doubt that for initial stage an initial investment for IBS requirement long term return by producing mass production.

Table 3. The Trend of Construction Industry in Malaysia

\begin{tabular}{|c|c|c|c|}
\hline Method & Traditional & Construction & Manufacturing \\
\hline Scope & Project based & Project based & Product based \\
\hline Project Specification & Short term & Short term & Long term \\
\hline Profit Earn & $\begin{array}{l}\text { Undefined profit or low profit } \\
\text { gain }\end{array}$ & Profit from customized solutions & $\begin{array}{c}\text { Profit in volumes of similar } \\
\text { products } \\
\text { (Gann 1996) }\end{array}$ \\
\hline Project Duration & Long period & $\begin{array}{c}\text { Possibility of project being } \\
\text { delayed } \\
\text { (Lim and Mohamed 2000, } \\
\text { Alaghbari } \text { et al. 2007) }\end{array}$ & $\begin{array}{l}\text { On time project completion / } \\
\text { meeting timeline } \\
\text { (Kadir } \text { et al. } 2005 \text { ) }\end{array}$ \\
\hline Applied technology & Manually & $\begin{array}{l}\text { Manually and semi } \\
\text { mechanization }\end{array}$ & $\begin{array}{l}\text { Higher mechanization due to } \\
\text { process repeatability and high } \\
\text { quality production }\end{array}$ \\
\hline $\begin{array}{l}\text { Transportation } \\
\text { requirement }\end{array}$ & Not important & Important & Very important \\
\hline Erection Procedure & Manually & Occasionally required & Very important \\
\hline Crane requirement & Not required & Occasionally required & Very important \\
\hline $\begin{array}{l}\text { Environmental } \\
\text { Awareness }\end{array}$ & $\begin{array}{l}\text { 3-D Syndrome (Dirty, Difficult } \\
\text { \& Dangerous) (IBS Survey } \\
\text { 2003) }\end{array}$ & $\begin{array}{l}\text { 3-D Syndrome (Dirty, Difficult } \\
\text { \& Dangerous) (IBS Survey } \\
\text { 2003) }\end{array}$ & $\begin{array}{l}\text { Environmental friendly and } \\
\text { recycled waste }\end{array}$ \\
\hline Type of workers & Required unskilled worker & $\begin{array}{l}\text { Required a large number of } \\
\text { unskilled worker }\end{array}$ & Using minimum skilled worker \\
\hline
\end{tabular}

In 2010, the total number of IBS manufacturer in Malaysia is 143. In the recent years, there are 21 suppliers and manufacturers, which were actively involved in the dissemination of IBS in Malaysia [1]. Majority of the IBS originated from the United States, Germany and Australia with a market share of 25\%, 17\% and 17\% respectively. Malaysia produced about $12 \%$ of the IBS systems [28]. The growth of IBS has increased almost seven times as reported by Badir [1]. Based on Table 1, Malaysia has expanded their R\&D IBS products into a more variety of categorization as such as steel framing system, timber framing system and innovative products system. Figure 3 shows the number of IBS products according to the classification groups. The highest number of IBS manufacturers is the precast concrete category followed by metal framing systems and timber framing manufacturer. The lowest numbers of IBS manufacturers are the innovative products system. Vice versa, based on the IBS Survey (2008) given to the same correspondent from 454 contractors in Malaysia on the most popular component used is steel framing system [27]. It was found that steel framing systems have become more popular compared to the precast concrete due to the time frame, cost effectiveness and quality impact of the completion project. An 
analysis to correlate with government mandatory rule pertaining to government funded construction projects using $70 \%$ of IBS components in proportion with the number of IBS manufacturer in each state [40].

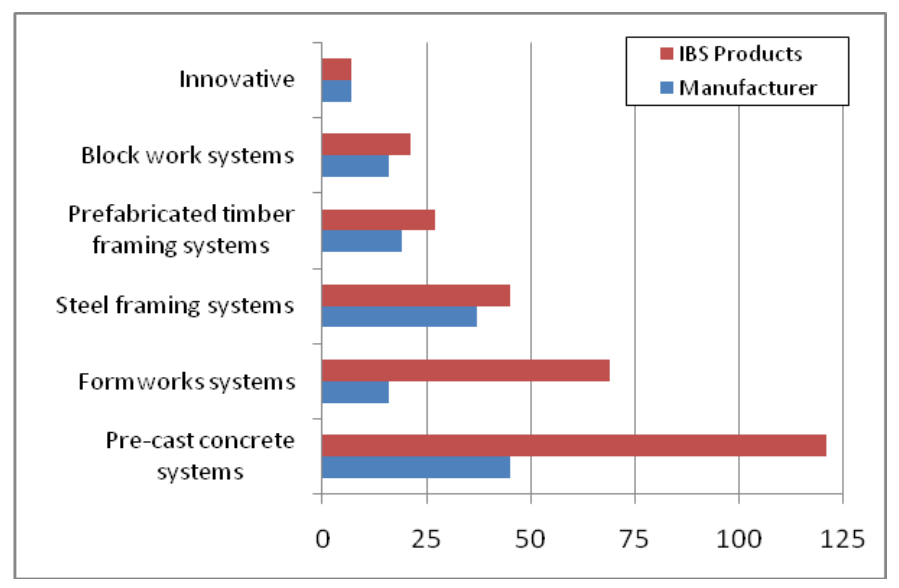

Figure 3. The Number of IBS Manufacturer and IBS Products (Source: IBS Info [41])

\section{CONCLUSION}

The vital issue on the awareness of Modern Method of Construction (MMC), Off-Site Manufacturing (OSM) and Industrialized Building System (IBS) has a common related drive and attribute constraints that started seriously in early 90 's. In addition, the global economic expansion and the growth of population causing the increase market price of houses has forced the government to be concern with the bottom billion to have an affordable houses. In Malaysia, the CIDB (Construction Industry Development Board) have played an important role in changing the paradigm of construction industry into more knowledgeable, achieving high skills and flexibility of competitive products having the same view as the construction industry in UK and Australia [24-27, 42]. Thus Malaysian government manage to educate the construction industry through mandatory law but offering good incentive to ensure contractors usage of IBS component in construction works.

The similarity and obstacle of OSCT, MMC, OSM and IBS is to have a break through to the end user and client's negative perspective of the architectural value as well as to make aware of the construction industry benefits when applying the off-site technology for the long term investment. In addition, the government and the financial support play an important role to ensure the policy and regulatory work well with the construction industry especially in training and adequate monetary aid to the small and medium entrepreneur. The main benefits will be high quality products, fast track completion projects, reduced foreign workers and changing the perception of construction industry market into the global market chain value.

The current trend of the IBS industry has gone through a few transitions from the conventional method to the prefabrication stages. The precast concrete system and steel framing system are the most popularly use in the IBS industry and the government needs to be responsive to this phenomenal change and provide more capital investment for automation and robotics technology in order to make Malaysia ahead in the transformation of the IBS industry. This research manages to determine the drive and barriers of OSCT, MMC, OSM and IBS manufacturing.

\section{ACKNOWLEDGMENT}

The authors wish to thank the Construction Industry Development Board (CIDB), Malaysia and Universiti Sains Malaysia (USM) for the providing the data.

\section{REFERENCES}

[1] Y. F. Badir, et al., "Industrialized Building Systems Construction in Malaysia," Journal of Architectural Engineering, vol. 8, pp. 19-23, 2002.

[2] A.-R. Abdul-Aziz, "Global strategies: a comparison between Japanese and American construction firms," Construction Management and Economics, vol. 12, pp. 473 - 484, 1994.

[3] D. M. Gann, "Construction as a manufacturing process? Similarities and differences between industrialized housing and car production in Japan," Construction Management and Economics, vol. 14, pp. 437 - 450, 1996. 
[4] R.-B. Richard, "Industrialised building systems: reproduction before automation and robotics," Automation in Construction, vol. 14, pp. 442-451, 2005.

[5] CII, "Constructability Implementation Guide," Construction Industry Institute, Austin1986.

[6] M. A. Nima, et al., "Constructability implementation: a survey in the Malaysian construction industry," Construction Management and Economics, vol. 19, pp. 819 - 829, 2001.

[7] B. Trigunarsyah, "A review of current practice in constructability improvement: case studies on construction projects in Indonesia," Construction Management and Economics, vol. 22, pp. 567 - 580, 2004.

[8] F. W. H. Wong, et al., "A study of measures to improve constructability.," International Journal of Quality \& Reliability Management, vol. 24, pp. 586-601, 2007.

[9] J. P. Womack, et al., The Machine that Changed the World. New York: Maxwell Macmillan International, 1990.

[10] M. Taylor, et al., "Automated Construction in Japan," Proceeding of the Institution of Civil Engineers, Civil Engineering, vol. 156, pp. 34-41, 2003.

[11] A. C. Webster, "Japanese Building Design and Construction Technologies," Journal of Professional Issues in Engineering Education and Practice, vol. 119, pp. 358-377, 1993.

[12] C. B. Tatum, "Constructability improvement using pre-fabrication, pre-assembly and modularization," Stanford University, California, US1986.

[13] C. Goodier and A. Gibb, "Future opportunities for offsite in the UK," Construction Management and Economics, vol. 25, pp. 585 - 595, 2007.

[14] N. Lu, "The Current Use of Offsite Construction Techniques in the United States Construction Industry," Seattle, Washington, 2009, pp. 96-96.

[15] BURA, "Steering and Development Forum Report: MMC Evolution or Revolution," British Urban Regeneration Association (BURA), London, United Kingdom2005.

[16] C. Goodier and A. Gibb, "Barriers and Opportunities for Offsite Production (OSP)," Loughborough University, Loughborough2004.

[17] C. Goodier and A. Gibb, "Buildoffsite," 2005.

[18] K. Hampson and P. Brandon, "Construction 2020: A vision for Australia’s Property and Construction Industry," Cooperative Research Centre for Construction Innovation for Icon.Net Pty Ltd, Brisbane2004.

[19] K. A. M. Kamar, et al., "Industrialized building system (IBS): revisiting the issues on definition, classification and the degree of industrialization," presented at the CIRAIC, 2009.

[20] CIDB, Industrialized Building System (IBS) Roadmap 2003-2010: Construction Industry Development Board (CIDB), Kuala Lumpur, 2003.

[21] A. G. F. Gibb and F. Isack, "Re-engineering through pre-assembly: client expectations and drivers," Building Research \& Information, vol. 31, pp. 146-160, 2003.

[22] CMAA, "FMI/CMAA Tenth annual survey of owner," 2010.

[23] CMAA, "FMI/CMAA Sixth annual survey of owner," 2006.

[24] N. Blismas and R. Wakefield, "Drivers, constraints and the future of offsite manufacture in Australia," Construction Innovation, vol. 9, pp. 72-83, 2008.

[25] W. Nadim and J. S. Goulding, "Offsite production in the UK: the way forward? A UK construction industry perpective," Construction Innovation, vol. 10, pp. 181-202, 2009.

[26] W. Pan, et al., "Perspectives of UK housebuilders on the use of offsite modern methods of construction," Construction Management and Economics, vol. 25, pp. 183 - 194, 2007.

[27] M. N. A. Azman, et al., "Perspective of Malaysian Industrialised Building System on the Modern Method of Construction," in The 11th Asia Pacific Industrial Engineering and Management Systems Conference, Malacca, Malaysia, 2010.

[28] M. R. A. Kadir, et al., "Construction performance comparison between conventional and industrialized building systems in Malaysia," Structural Survey, vol. 24, pp. 414-424, 2005.

[29] IBS, "IBS Survey 2008," Construction Industry Development Board (CIDB)2008.

[30] D. N. Trikha and A. A. A. Ali, Industrialized Building Systems: Universiti Putra Malaysia Press Construction Industry Development Board (CIDB), 2004.

[31] ManuBuild, "Open Building Manufacturing: Core Concepts and Industrial Requirements," A. S. Kazi, et al., Eds., ed Finland: ManuBuild VTT-Technical Research Centre of Finland, 2007.

[32] M. Edge, et al., "Overcoming Client and Market Resistance to Prefabrication and Standardization in Housing Robert Gordon University " 2002.

[33] B. Roskrow, Design and Deliver: Housebuilder, 2004.

[34] M. o. H. a. L. Government, "Housing Strategies and Programmes in Malaysia. Report," National Housing Department., Research and Development Division, Malaysia1997.

[35] W. Alaghbari, et al., "The significant factors causing delay of building construction projects in Malaysia," Engineering Construction and Architectural Management, vol. 14, pp. 192-206, 2007.

[36] C. S. Lim and M. Z. Mohamed, "An exploratory study into recurring construction problems," Int J Project Management, vol. 18, pp. 267-273, 2000.

[37] Lembaga Pembangunan Industri Pembinaan Malaysia, L. o. Malaysia ACT 520, 1994.

[38] Z. Abd. Hamid, et al., "Industrialized Building Systems (IBS) in Malaysia: The Current State and R\&D Iniatives," Malaysia Construction Research Journal, vol. 2, pp. 1-13, 2008. 
[39] CIDB, "Industrialized Building Systems in Malaysia," Construction Technology Development Division, Kuala Lumpur2006.

[40] Treasury, "Application Industrialized Building System (IBS) in Government Project," M. o. Finance, Ed., ed, 2008. [41] IBS, Construction Industry Development Board2010.

[42] N. Blismas, et al., "Benefit evaluation for off-site production in construction," Construction Management and Economics, vol. 24, pp. 121 - 130, 2006. 